\title{
ON THE CELLULAR REACTIONS INDUCED BY LOCAL DEPOSITS OF CHOLESTERIN IN THE TISSUES. ${ }^{1}$
}

\author{
By Matthew J. Stewart, M.B., M.R.C.P. \\ From the Pathological Department of the General Infirmary, Leeds. \\ (Plates XXI.-XXII.) \\ PART I. \\ UNDER PATHOLOGICAL CONDITIONS IN THE HUMAN \\ SUBJECT.
}

THE present communication is concerned primarily with the cellular reactions occasionally induced in the tissues of the human subject by pathological deposits of crystalline cholesterin, and especially with the appearance therein of giant cells of the foreign-body type, but it will be well in the first place to consider very briefly the various conditions under which such deposits occur.

In man, cholesterin is a normal constituent of all cellular tissues, in which it occurs in solution or in a colloidal state, in association with lecithin and other lipoid substances. It is also found in crystalline form in the cells of the adrenal cortex and corpus luteum, where it is generally regarded as a secretory product of the epithelial cells (Powell White, $1909^{1}$ ). Under pathological conditions, deposits of crystalline cholesterin occur with considerable frequency, and in a variety of lesions. Such deposits are usually in large part extracellular, occasionally entirely so, sometimes entirely intracellular, and as there are all gradations between those extremes, the histological characters of the lesion produced are found to vary very greatly in different cases.

\section{Conditions of Occurreance of Pathological Derposits of Crystalitine Cholrsterne.}

A great deal of work has been done on this subject within recent years, an excellent summary of which is given by $\mathrm{M}^{\mathrm{N}} \mathrm{Nee}\left(1914^{2}\right)$. In much of the work which he quotes, the great influence of hyper-

[suceived July 6, 1914.] Communicated to the Pathological Society of Great Britain and Ireland, June 26-27, 1914.

21-JL, or PATB.-VOL. xxx. 
cholesterinæmia in the genesis of local cholesterin deposits is rightly insisted on, but it must be borne in mind that in a very large number of cases this change is due essentially to tissue disintegration, and may be quite unassociated with any increase in the cholesterin content of the blood.

Local cholesterin deposits may therefore be classified etiologically as follows:

A. Those which are due solely or principally to local tissue changes.

1. As a result of tissue necrosis, with no means of escape for the products of disintegration, e.g., tuberculous caseation, arterial atheroma, necrosis in tumours, degeneration cysts of thyroid, ovary, and other organs, old cataractous lenses, and many lesions of the lung associated with necrosis.

2. By the retention of various lipoid-containing secretions, exudations, and desquamation products, e.g., milk in certain cases of chronic mastitis and tubercle of the breast, pus in old pyosalpinx and long-standing empyemas, and the epidermic débris of dermoid cysts, cholesteatomas, testicular teratomas and epitheliomas.

3. In tumours generally, and especially in carcinomas, apart from any necrotic changes-Powell White $\left(1909^{3}\right)$.

$B$. Those which are apparently due to an actual excretion or extravasation of cholesterin from the blood during the course of a hypercholesterinæmia, e.g., cholesterin gall-stones, xanthoma, arcus senilis, possibly some forms of arteriosclerosis, and the white spots of albuminuric and diabetic retinitis.

Powell White $\left(1909^{3}\right)$, in his paper "On the Occurrence of Crystals in Tumours," has given an admirable account of the different forms of crystalline cholesterin met with in the tissues, and my own observations, in so far as they deal with this subject, go to confirm his results. With regard to subdivisions 1 and 2 of class $A$ in the above table, i.e., those lesions which are associated with retrograde tissue changes, and with the retention of cellular products of various sorts, the sequence of events is probably as follows. The cellular cholesterin is normally held in solution or in a colloidal state by lecithin and other lipoid substances. When necrosis of the cell takes place, this combination is broken down and the liberated cholesterin is deposited in situ in a crystalline form, either as pure or nearly pure cholesterin, or as a compound or loose combination with fatty acidsPowell White $\left(1909^{3}\right.$ ), Craven Moore (1907 ${ }^{4}$ ). 
The pure cholesterin occurs most frequently in the form of the well-known rhomboid crystals, occasionally as bunches of fine needles or prisms. The combination of cholesterin and fatty acid is also found in two forms, namely, as needle-like crystals similar to those just mentioned, and as anisotropic globules and cylindrical myelin forms. The needles in the latter case differ from the former in that when heated to varying temperatures $\left(30^{\circ}\right.$ to $70^{\circ} \mathrm{C}$.) they melt to form spherical globules which on cooling show the phenomena of anisotropism for a longer or shorter period, and it is possible that during life they are actually present in the tissues in this fluid crystalline state-Adami $\left(1910^{5}\right)$. All four varieties of crystals are doubly refractile.

In the case of tumours, Powell White has shown that the crystals present in and among the healthy living cells consist of this same combination of cholesterin and fatty acid, and that in formalin fixed material they may be found either as needles or as anisotropic globules. The plates and needles of pure or nearly pure cholesterin, on the other hand, are all extracellular, and occur only in the necrotic parts.

In the case of xanthoma, arcus senilis, and the retinal white spots of diabetes and chronic nepbritis, the lipoid is chiefly intracellular, and is stated to be present in the form of cholesterin esters-Pollitzer and Wile $\left(1912^{6}\right)$, Chauffard $\left(1911^{7}\right)$, etc.

\section{Ceilular Reactions induced by Cholesterin Deposits.}

This is a subject which seems to have received very little attention in pathological literature, especially in this country. Mallory (19148) deals at some length with certain aspects of the question in a recently published text-book, while Roussy $\left(1913^{9.10}\right.$ ) made a short communication on the subject at the Seventeenth International Congress of Medicine. This author had previously described and figured the condition as it occurs in cholesteatomata of the choroid plexus in the horse, and in two cases of cholesteatoma in man.

All local deposits of cholesterin in the tissues do not give rise to foreign-body giant cells, and many of them, indeed, are unassociated with cellular reactions of any sort. One proviso is all important, namely, that the crystals should be deposited in the midst of the living cellular connective tissues, without the intervention of either a necrotic or an epithelial layer. In atheroma and tuberculous caseation, for example, the cholesterin is embedded in the midst of a necrotic mass, and is unable to exert any chemiotactic or other influence on the living tissues at the margin. Similarly, in some dermoid cysts and highly keratinous squamous epitheliomas, the cholesterin-containing masses of epithelial débris are surrounded by a complete lining of living epithelium which apparently protects the subjacent tissues from irritation-Stewart (1913 $\left.{ }^{11}\right)$. 
For the formation of foreign-body giant cells an additional factor appears to be necessary, namely, that the deposited cholesterin be extracellular, and it will be further shown that in the great majority of the specimens examined it is the tabular form of this substance which is present.

The following observations are based on the study of nearly fifty specimens showing the changes described, of which thirteen have been investigated in frozen sections with the aid of the polarising microscope. The first examples studied, and a considerable number of the later ones, were accidental discoveries in paraffin-embedded material, and in a majority of these cases this was all that was available for purposes of further study. In some, however, the original specimen preserved in formalin had been kept, and latterly I was able to tell what was likely to be suitable material, and to deal with it accordingly.

METHODS.-The paraffin sections, all from formalin fixed material, were stained with the ordinary dyes, especially hæmalum and eosin. A few were stained by Mallory's method with acid fuchsin, 'anilin blue and orange $G$, and some with Pappenheim's methyl-green-pyronin mixture. The frozen sections, also formalin fixed, were stained with Nile blue sulphate A (Lorrain Smith), which was found to give excellent results, and a few with Scharlach $R$, and hæmatoxylin. They were examined both in the ordinary way and with the polarising microscope.

\section{Histological Appearances.}

Intracellular crystalline cholesterin, especially when present in any amount, is always associated with what has been described, in paraffin sections, as a foamy appearance of the cytoplasm. This is well seen, under physiological conditions, in the cells of the adrenal cortex, especially the zona fasciculata, and in the recent or fairly recent corpus luteum. Under pathological conditions, the appearance is found chiefly in the case of endothelial cells, and constitutes one of the most striking characteristics of a great variety of lesions. A similar phenomenon is sometimes observed in epithelial cells also, as in hypernephromas, and papilliferous cystomas of the kidney. How much of the "foamy" appearance is actually due to the cholesterin present it is difficult to say, since, in these cases, this substance is always associated with greater or smaller amounts of neutral fats and other lipoid substances. Indeed, foamy cells of apparently precisely similar characters are occasionally found in which no doubly refracting material can be detected. The affected cells show up prominently in paraffin sections by reason of their faintly staining, finely granular cytoplasm, especially when they occur in groups, and also as they are possessed of a very well defined limiting membrane. The nuclei are small and darkly stained, and may be situated centrally or peripherally. Each cell usually possesses one nucleus only, but occasionally two or three are present. 
The appearance in frozen sections stained with Nile blue sulphate varies considerably in different cases. Cholesterin is usually present in the form of fine needle-like crystals, unstained and donbly refracting, occasionally as fluid crystals, i.e., doubly refracting globules with or without the cross of polarisation. The globules may be unstained, or may be coloured pink or blue from association with other lipoids. That this appearance is not due to reflection from stained structures in the neighbourhood is shown by the fact that the globules can be displaced into the surrounding medium, when they still show the same colour reactions. In some cases, as already indicated, the foamy cells contain no crystalline cholesterin; in others, as for example, hypernephromas, the crystals are present in enormous numbers. The other lipoid constituents of these cells consist in some cases chietly of pinkstaining globules of neutral (glyceryl) fats, in others of blue-stained globules, with various mixtures and combinations of the two, but I have not investigated these points any further.

Some of the giant cells, to be described presently, also contain similar areas of foamy cytoplasm, due apparently to the accumulation of similar lipoid substances.

In the absence of any systematic chemical investigation, or study of the melting points of these crystals, it is not intended to enter into the debated question of their precise nature, whether they are to be regarded as actual cholesterin esters-Adami and Aschoff (1906 ${ }^{12}$ ) - or merely as loose combinations of cholesterin with fatty acids-Powell White $\left(1908^{13}\right)$, Craven Moore $\left(1907^{4}\right)$, Lorrain Smith (1909 $\left.{ }^{14}\right)$.

It may be noted here that when foamy cells are present in large numbers they show up to the naked eye as opaque yellow areas, similar in colour and appearance to the outer parts of the adrenal cortex.

That the extracellular deposits consist of pure or nearly pure cholesterin there seems to be little doubt, especially when, as is usually the case, the crystals present are of the rhombic or plate variety. In paraffin sections, deposits of plate cholesterin give rise to a very characteristic appearance, namely, that of elongated oval or cigar-shaped spaces, with sharply cut margins and devoid of contents. They show great variation in size, from tiny clefts not exceeding $10 \mu$ in length to huge elongated spaces extending across the whole lowpower field of the microscope. Apart from this, their appearance is so constant and characteristic that I think the term "cholesterin clefts" might suitably be employed to describe them, and that whether they occur in purely necrotic areas, as in arterial atheroma, or in the midst of living cellular tissues, as in the walls of cholesteatomata and dermoid cysts. The clefts lie scattered about in all directions, except that when subjected to pressure, as in the situations mentioned, they tend to lie more or less parallel to the free surface. That they are due to the presence of cholesterin plates is shown 
conclusively by the examination of frozen sections, in which the doubly refracting crystals of that substance can be seen exactly filling the clefts. Being of extreme thinness, the crystals are generally shown cut across, but occasionally one is seen on the flat, when a more or less typically rhombic structure can frequently be made out. Occasionally, large irregular spaces containing a mass of crystals occur.

When deposited in the midst of living connective tissue, plate cholesterin gives rise to a very pronounced cellular reaction, characterised especially by the presence of numerous giant cells of the foreignbody type. These surround in whole or in part the cholesterin clefts, against which, or rather against the contained crystals of which, they are often flattened out in a curious way. When the clefts are of small size they may be contained within a single giant cell, when large they may be surrounded by quite a number. Sometimes there is obvious cytoplasmic continuity between adjacent giant cells, giving rise to an appearance as if the crystals were embedded in one large sprawling plasmodial mass. This, I think, clearly shows that cellular fusion plays some part in the genesis of these cells. In addition to those which line the clefts, giant cells are frequently present in large numbers in the intervening stroma, together with varying numbers of foamy endothelial cells and fibroblasts (Plate XXI. Fig. 1). The giant cell cytoplasm is very homogeneous and stains deeply with eosin, often in striking contrast to the surrounding tissues. This contrast can be greatly intensified, as in Plate XXI. Fig. 1, by over-staining in watery eosin, followed by hæmalum, and then washing in water for several hours. The nuclei are numerous, small, and darkly stained, and are usually irregularly distributed throughout the cell. In some specimens, certain of the giant cells, especially the smaller ones, show areas of foamy cytoplasm similar to that of the adjacent foamy endothelial cells, and this is shown to be due to the presence of similar lipoids, with or without cholesterin. In these partly fatty cells the nuclei are clumped together, and the cytoplasm inmediately surrounding them is homogeneous and deeply stained, the foamy areas being usually peripherally situated. This appearance seems to afford some evidence in favour of the view that the giant cells take origin from the endothelial cells, as does the fact that it is often possible to trace all transitions from one type of cell to the other. $\mathrm{In}$ two instances, also, where many of the endothelial cells were filled with brownish pigment, resulting from ancient hæmorrhage, giant cells in the neighbourhood were seen to be in part similarly affected.

\section{Conditions of Occurrence of Giant Cell Lesions.}

I have now observed foreign-body giant cells in immediate relation to local cholesterin deposits in the following lesions:- 
1. Cholesteatoma, 2 cases.

(a) of temporo-sphenoidal lobe.

(b) of middle ear.

2. Ovarian dermoid, 5 cases.

3. Fpidermic cysts in other situations, 7 cases.

(a) of breast (so-called "cholesteatoma"), 2 cases.

(b) of branchisl cleft.

(c) of thyroglossal duct.

(d) of thumb ("implantation dermoid").

(e) of thigh.

(f) of mastoid.

4. Squamous epithelioma, 11 cases.

(a) primary, 4 cases.

(b) secondary depnsits in lymph glands, 7 cases.

5. Gall-bladder wall in cholelithiasis, 3 cases. In two of these the gall-stone was of the "solitary cholesterin" type.

6. Mastitis, simple subacute and tuberculous, 6 cases.

7. Old pyosalpinx, 2 cases.

8. Teratoma of testis, 2 cases.

9. Cystic necrotic nodule in thyroid, 2 cases.

10. Necrotic cyst of ovary, 1 case.

11. Fibro-xanthomatous tumour, 1 case.

12. Dentigerous cyst, $1^{\prime}$ case.

13. Obstructed cyst in hyperkeratosis of tonsil, 1 case.

14. Cystic adenocarcinoma of ovary, 1 case.

15. Lupus verrucosus, 1 case.

16. Subacute inflammatory lesion of adipose tissue, 1 case.

Of these forty-seven specimens, thirteen were studied in frozen sections with the polarising microscope, namely, three gall bladders, two epidermic cysts, and one each of the following:-Chronic mastitis, epithelioma of tongue, cholesteatoma of brain, fibro-xanthoma, pyosalpinx, adenocarcinoma of ovary, dentigerous cyst, and inflamed adipose tissue.

The general histological description already given may be applied, with but little modification, to the great majority of these cases, - the principal difference between individual specimens being in the amount of cholesterin deposited, and consequently in the number of giant cells and foamy cells present. Special note must be made, however, of cholesterin deposits occurring in the breast, as these illustrate the formation of giant cells around bunches of acicular cholesterin crystals, a very unusual event.

\section{Cholesterin Deposits in the Breast.}

There is an appearance occasionally seen in the breast in cases of subacute and tuberculous mastitis which is clearly the result of local deposits of cholesterin. It consists, in paraffin sections, in the presence of a number of "giant cell rosettes" scattered throughout the inflammatory tissue. The microscopic appearance is most characteristic (Plate XXII. Fig. 3), and consists of a central lumen of varying size, around which is arranged a more or less perfect ring of 
typical foreign-body giant cells. The latter are rounded off and well defined externally, but in their inner aspect they show a series of fine cytoplasmic prolongations or fibrillæ running in to the centre of the space. A study of frozen sections shows that this curious appearance is due to the presence in the lumen of a radiating bunch of acicular crystals of cholesterin (Plate XXI. Fig. 2), the peripheral extremities of which actually penetrate the interstices between the giant cells. The granulomatous tissue surrounding these rosettes contains numerous foamy endotbelial cells and a number of independent giant cells with partly foamy cytoplasm, an appearance which is due, as before, to the presence of lipoid substances, including cholesterin.

I have now found this curious lesion on four occasions, namely, in two cases of apparently primary tuberculosis of the breast, and in two cases of simple subacute mastitis. The condition is undoubtedly due to duct obstruction, with retention of the secretory products, from which subsequently the cholesterin crystallises out in acicular form. This is shown by the fact that some of the dilated ducts are lined in part by the original epithelium, in part by a giant cell layer, similar to that described. All four patients were multiparous, and in three of them the interesting fact was elicited that none of the children had been suckled on the affected breast. In the fourth case the patient suffered from an abscess of the breast during the nursing of her eighth child, and three subsequent children were suckled with the healthy breast only. These four are the only examples in the present series of a giant cell lesion due to deposition of acicular cholesterin, and it will be observed that the histological characters are rather different from those of plate cholesterin deposits. In one of these breasts, typical cholesterin clefts with associated giant cells were present in addition, and in two other cases of mastitis, clefts and giant cells were present without giant cell rosettes (Plate XXII. Fig. 6).

\section{Conclusions.}

1. Crystalline cholesterin is deposited in the tissues in various forms and under various pathological conditions.

2. Deposits of the tabular crystals give rise, in paraffin sections, to a very characteristic appearance, namely, that of "cholesterin clefts."

3. When the deposits occur in the midst of the living connective tissues, they give rise to a very special cellular reaction, characterised by the presence of numerous "foamy" endothelial cells, and by varying numbers of giant cells of the foreign-body type.

4. This giant-cell reaction is generally induced by the tabular form of cholesterin, but in some inflammatory breast lesions with retentions of the secretions, eccicular cholesterin is deposited within the dilated ducts, and leads to the formation of very striking and characteristic "giant cell rosettes." 
5. Appearances point to the giant cells being derived from the endothelial cells; in part, at least, by a process of fusion.

6. Cholesterin must therefore be regarded as a very potent and widely acting stimulant to the formation of foreign-body giant cells in human pathological processes.

\section{REFERENCES.}

1. C. Powrer Whitr. . . "On the So-called Fatty Degeneration of the Adrenals," Journ. Path. and Bacteriol., Cambridge, 1909, vol. xiii. p. 11.

2. J. W. M'NER . . . . "Cholesterin: An Account of its Relations to Pathology and Physiology," Quart. Journ. Med., Oxford, 1914, vol. vii. p. 221.

3. C. PowhLL WhITE . . "On the Occurrence of Crystals in Tumours," Journ. Path. and Bacteriol., Cambridge, 1909, vol. xiii. p. 3.

4. F. CRaven Moore. . . "Cholesterin: Some Accounts of its Chemical, Physical, and Biological Relations," Med. Chron., Manchester, 1907, vol. xlvii. p. 204.

5. J. Grorgr Adami . . " "The Principles of Pathology," vol. i. General Pathology, London. Second Edition, 1910, pp. 94, 918, et seq.

6. S. Polutuzar and Udo J. "Xanthoma Tuberosum Multiplex," Journ. WILr Cutan. Diseases, New York, 1912, vol. xxx. p. 235.

7. A. Chaufrard . . . . "Les Dépôts Locaux de Cholesterine et leurs rapports avec la Cholesterinæmie," Rev. de méd., Paris, 1911, tome xxxi. p. 176.

8. F. B. MaLLoRY . . . "The Principles of Pathologic Histology," Philadelphia and London, 1914.

9. Gustave Roussr . . . "Sur les Réactions Cytologiques produites dans Les Tissus par les Dépôts Locaux de Cristaux de Cholesterine," Compt. rend. Soc. de biol., Paris, 1913, tome lxxv. p. 18, and Trans. Seventeenth Internat. Cong. of Med., London, 1913, Section III., Gen. Path. and Path. Anat., Part II., p. 185.

10. Gustave Roussy . . . "Les Cholesteatomes," Bull. As8oc. franc. pour l'étude du Cancer, Paris, November 1912.

11. M. J. STRWART . . . “On the Occurrence of Irritation Giant Cells in Dermoid and Epidermoid Cysts," Journ. Path. and Bacteriol., Cambridge, 1913, vol. xvii. p. 502.

12. J. Grorgr Adami $\triangle$ ND L. "On the Myelins, Myelin Bodies, and AschorF Potential Fluid Crystals of the Organism," Proc. Roy. Soc. London, Series B, 1906, vol. lxxvii. p. 359.

13. C. PowkLL Whirr . . "Cholesterol, Fluid Crystals, and Myelin Forms," Med. Chron., Manchester, 1908, vol. xlvii. p. 403.

14. J. Lorrain SMith AND W. "An Investigation of the Principles UnderMaIR Iying Weigert's Method of Staining Medullated Nerve," Journ. Path. and Bacteriol., Cambridge, 1909, vol. xiii. p. 14. 


\section{DESCRIPTIONS OF PLATES XXI.-XXII.}

\section{Plate XXI.}

Fra. 1.-Portion of a cholesteatomatous polypus from the ear, showing "cholesterin clefts" surrounded by giant cells, and "foamy "endothelial cells. Hæmalum and eosin. $(x 250$.

Fig. 2.-From a case of subacute mastitis. Frozen section stained with Nile blue sulphate A, showing a bunch of acicular cholesterin crystals surrounded by a ring of giant cells. Note the presence of numerous other giant cells, and violet stained foamy cells. $(\times 125$. $)$

\section{Plate XXII.}

Frg. 3.-A typical "giant cell rosette" from the same case as Fig. 2, showing the appearance found in paraffin sections. $(\times 90$.)

Fro. 4.-Cholesterin deposited in the wall of the gall bladder, showing numerous clefts and a few giant cells. $(\times 70$.

Fra. 5.-Microphotograph from same case as Fig. 1. ( $\times 70$.

FIG. 6.-Portion of necrosing sarcoma showing cholesterin clefts and foamy cells, but no giant cells. $(\times 70$.

Fics. 1, 2, and 3 are from drawings by Miss Ethel Wright.

Figs. 4, 5, and 6 from microphotographs. 


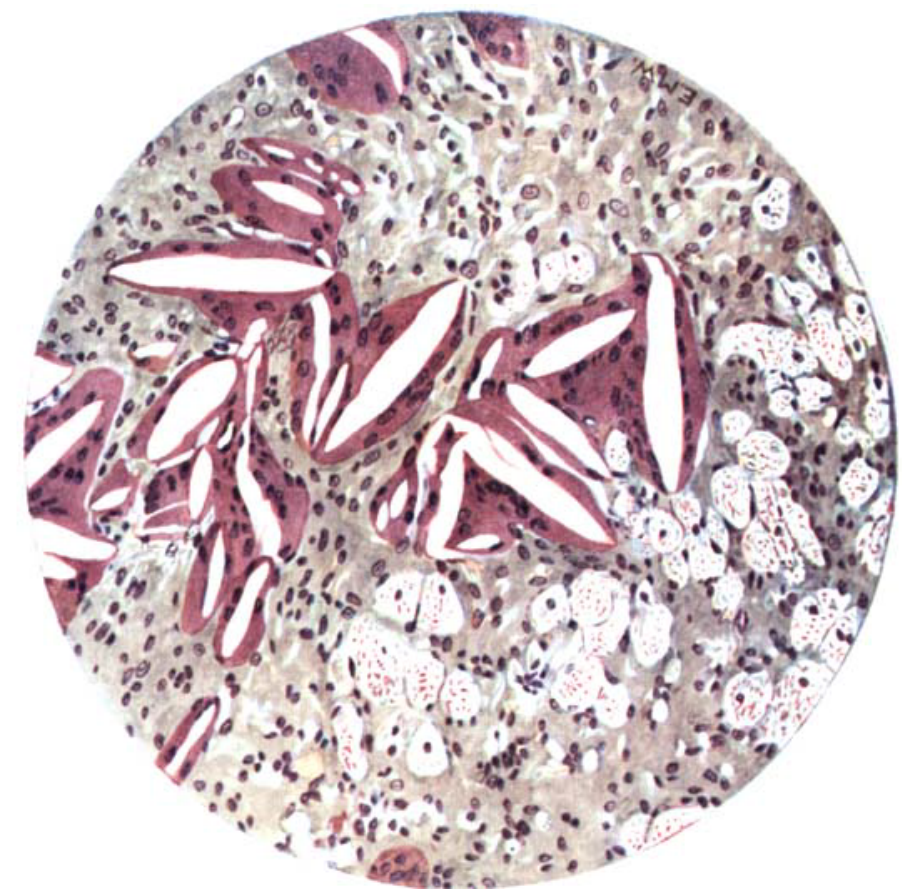

Fre. 1.

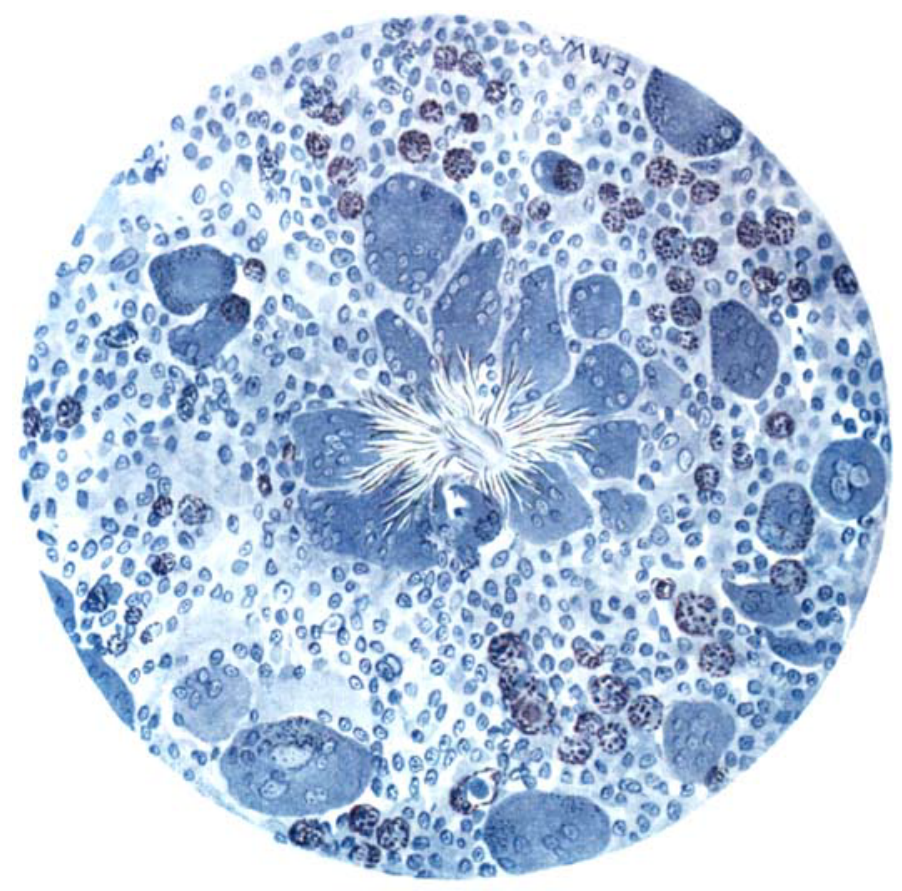

Fic. 2. 


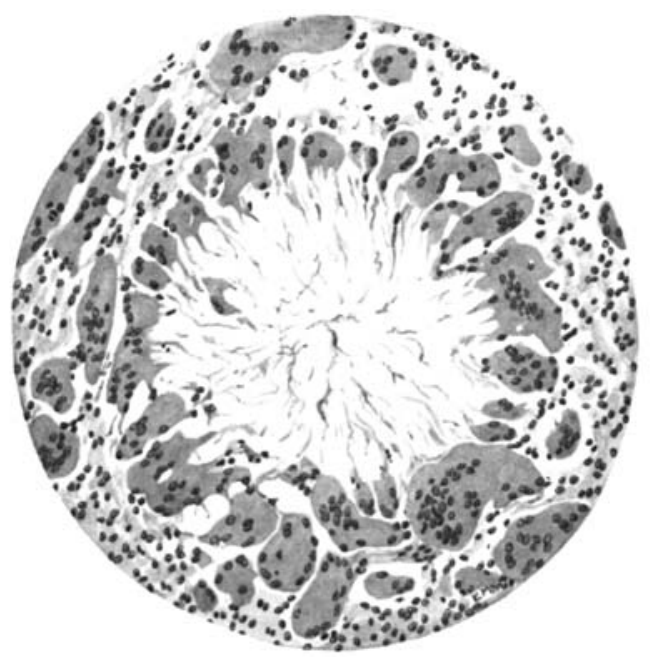

Fia. 8.

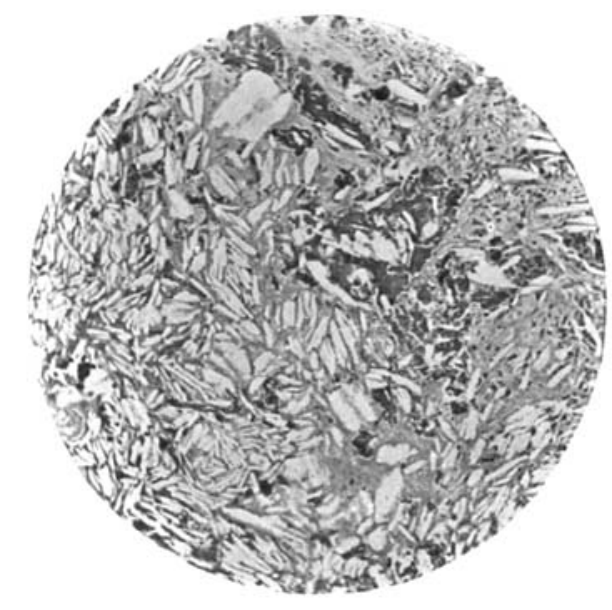

FIG. 4.

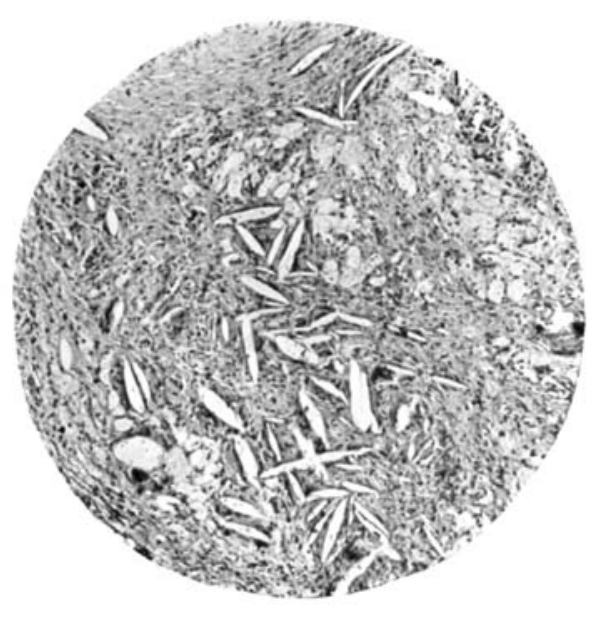

Fre. 5.

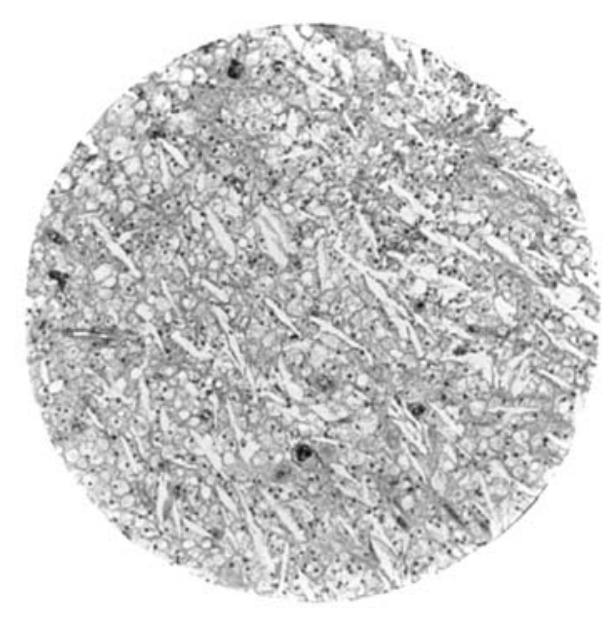

Fia. 6. 